\title{
PERANCANGAN SISTEM APLIKASI DESKTOP PENAGIHAN ANGSURAN SISWA PADA BKB NURUL FIKRI
}

\author{
Yusuf Efendi', Syamsiah $^{2}$, Noor Komari Pratiwi ${ }^{3}$ \\ 1,2,3 Universitas Indraprasta PGRI \\ Jl. Raya Tengah No. 80, Kel. Gedong, Kec. Pasar Rebo, Jakarta Timur 13760, Jakarta \\ 1yusufefndi96@gmail.com, ${ }^{2}$ ncham.unindra08@gmail.com, ${ }^{3}$ noorkomaripratiwi01@ gmail.com
}

\begin{abstract}
ABSTRAK
Tujuan dari penelitian ini adalah untuk merancang dan menerapakan suatu sistem aplikasi penagihan angsuran siswa yang dapat membantu dan mempermudah staf administrasi Bimbingan dan Konsultasi Belajar Nurul Fikri dalam proses penagihan angsuran siswa di lokasi belajar. Metode penelitian yang digunakan adalah penelitian kualitatif dengan metode studi lapangan untuk pengambilan data, yaitu melalui pengamatan langsung, wawancara dengan pihak terkait, serta melakukan dokumentasi untuk mendapatkan informasi yang dibutuhkan. Metode pengembangan sistem yang digunakan adalah metode Waterfall. Hasil dari penelitian ini adalah adanya suatu perangkat aplikasi yang dibuat dengan bahasa pemrograman Java NetBeans dan penyimpanan data menggunakan database dari MySQL. Dalam membangun sistem ini, digunakan alat bantu perancangan sistem yaitu Diagram Aliran Data (DAD) Konteks, Nol dan Rinci. Sistem aplikasi yang dirancang ini dapat membantu dan mempermudah staf administrasi dalam melakukan proses penagihan angsuran siswa di lokasi belajar Nurul Fikri.
\end{abstract}

Kata Kunci: Angsuran Siswa, Java, $M y S Q L$, Penagihan, Sistem Aplikasi.

\begin{abstract}
The purpose of this study is to design and implement a student installment billing application system that can assist and facilitate the administrative staff of Nurul Fikri's Guidance and Learning Consultation in the student installment billing process at the study location. The research method used is qualitative research with field study methods for data collection, namely through direct observation, interviews with related parties, and conducting documentation to obtain the required information. The system development method used is the Waterfall method. The result of this research is the existence of an application device that is made with the Java NetBeans programming language and data storage using a database from MySQL. In building this system, system design tools are used, namely Context, Zero and Detailed Data Flow Diagrams (DAD). This application system designed can help and facilitate administrative staff in carrying out the student installment billing process at Nurul Fikri's study location.
\end{abstract}

Key Word: Application System, Billing, Java, MySQL, Student Installment.

\section{PENDAHULUAN}

Perkembangan teknologi dan sistem informasi saat ini sangat dibutuhkan oleh lembaga, organisasi atau instansi terutama teknologi informasi yang dilakukan melalui media internet. Hal ini diwujudkan dengan adanya komputerisasi sebagai alat bantu yang mampu menyimpan dan mengelola berbagai macam data secara cepat, tepat, dan akurat.

Kemajuan teknologi informasi khususnya di bidang komputer sangat erat hubungannya dalam menunjang kegiatan manusia untuk mempermudah penyelesaian masalah. Penggunaan komputer dan sistem informasi khususnya saat ini sudah banyak digunakan di semua bidang seperti pada bidang pendidikan dan keuangan (Rusman \& Ramanda, 2018).
Lembaga pendidikan yang dimaksud dalam penelitian ini adalah Bimbingan dan Konsultasi Belajar Nurul Fikri. Lembaga pendidikan ini memberikan bimbingan belajar kepada siswa/siswi yang memiliki semangat belajar tinggi dalam rangka mempersiapkan diri untuk menghadapi Penilaian Akhir Semester (PAS), Penilaian Akhir Tahun (PAT), Ujian Sekolah (US), dan Seleksi Bersama Masuk Perguruan Tinggi Negeri (SBMPTN). Hal ini sesuai dengan teori yang menyatakan bahwa tujuan bimbingan belajar adalah membantu siswa agar mampu mengatasi dan memecahkan permasalahan belajarnya agar tidak mengganggu perkembangannya (Saman \& Arifin, 2018).

Lembaga pendidikan ini menerapkan dua metode pembayaran terhadap siswa yang 
ingin melakukan pendaftaran, yaitu tunai dan angsuran. Dengan membayar minimal angsuran pertama dan biaya formulir di awal, siswa sudah bisa menikmati fasilitas belajar yang dapat digunakan selama 1 tahun ajaran.

Fasilitas yang diberikan oleh Bimbingan dan Konsultasi Belajar Nurul Fikri tentunya diimbangi dengan kewajiban para siswa dalam melakukan pembayaran. Pelaksanaan pembayaran harus sesuai dengan perjanjian sehingga sistem pembayaran atas produk jasa tersebut menjadi sistem yang berjalan sesuai dengan kebijakan-kebijakan yang telah ditetapkan.

Sistem penagihan angsuran siswa yang dilakukan di Bimbingan dan Kosultasi Belajar Nurul Fikri masih menggunakan sistem penagihan yang sederhana, salah satu contoh yaitu dalam melakukan penagihan angsuran siswa yang sudah jatuh tempo dengan menggunakan Microsoft Word untuk mencetak template surat, kemudian untuk nama dan keterangan tagihan masih ditulis tangan sehingga surat terkesan kurang profesional jika diterima oleh pihak yang akan ditagih.

Tujuan dari penelitian ini adalah merancang sistem aplikasi penagihan angsuran siswa sehingga data menjadi lebih valid dan bisa langsung diolah ke dalam database yang dapat mempercepat proses pembuatan laporan yang berkaitan dengan data penagihan angsuran siswa sesuai dengan kebutuhan.

Penagihan merupakan serangkaian tindakan yang dilakukan pihak penagih terhadap konsumen agar konsumen melunasi utang dan biaya penagihan yang telah disepakati dalam akad. Dalam tindakan penagihan, penagih diberikan kewenangan untuk menegur atau memperingatkan, melaksanakan penagihan seketika dan sekaligus, memberikan surat, dan mengusulkan pencegahan (Hidayat \& Cheisviyanny, 2013).

Perancangan sistem adalah suatu kegiatan membuat desain teknis berdasarkan pada waktu proses analisis (Kristanto, 2013).

Aplikasi adalah alat terapan yang difungsikan secara khusus dan terpadu sesuai kemampuan yang dimilikinya (Sutabri, 2012).
Berdasarkan penjelasan di atas, dirancanglah sistem aplikasi desktop penagihan angsuran siswa pada BKB Nurul Fikri. Dengan menggunakan suatu sistem aplikasi penagihan angsuran siswa berbasis java, diharapkan sistem ini dapat membantu sistem administrasi agar menjadi lebih efektif dan efisien dalam penagihan angsuran siswa, data tersimpan menjadi lebih aman, dan kemudahan dalam pembuatan laporan.

Hal tersebut sama seperti hasil penelitian bejudul Penerapan Global Extreme Programming Pada Sistem Informasi Pembayaran Angsuran Bimbingan Belajar yang menyatakan bahwa sebuah sistem yang sudah terkomputerisasi dengan baik adalah salah satu pemecahan masalah karena proses pengolahan data khususnya pembayaran dapat dilakukan lebih cepat dan tepat (Rusman \& Ramanda, 2018).

\section{METODE PENELITIAN}

Rancangan kegiatan dimulai pada bulan Maret 2021 dengan cara mengadakan survei langsung ke tempat penelitian diadakan, yaitu dengan observasi dan dokumentasi. Penelitian dilakukan di Bimbingan dan Konsultasi Belajar Nurul Fikri yang terletak di Mampang Prapatan XV No. 1 RT 013/ RW 001 Kelurahan Tegal Parang Kecamatan Mampang Prapatan, Jakarta Selatan dimulai selama 5 bulan pada bulan Maret tahun 2021 sampai dengan bulan Juli tahun 2021.

Metode penelitian yang digunakan yaitu metode penelitian kualitatif. Penelitian kualitatif adalah penelitian yang tidak menggunakan model-model matematik, statistik atau komputer. Proses penelitian dimulai dengan menyusun asumsi dasar dan aturan berpikir yang akan digunakan dalam penelitian. Penelitian kualitatif merupakan penelitian yang dalam kegiatannya peneliti tidak menggunakan angka dalam mengumpulkan data dan dalam memberikan penafsiran terhadap hasilnya (Mamik, 2015).

Langkah-langkah pengembangan sistem yang digunakan penulis dalam pengembangan sistem aplikasi desktop penagihan angsuran siswa pada Bimbingan dan Konsultasi Belajar Nurul Fikri dengan menggunakan metode pengembangan model waterfall. Model air terjun menyediakan pendekatan alur hidup 
perangkat lunak secara sekuensial atau urut dimulai dari analisis, desain, pengkodean, pengujian dan tahap support (A.S \& Shalahuddin, 2011).

Bahasa pemrograman yang digunakan adalah java. Java merupakan bahasa pemrograman yang sejatinya berbasis object oriented programing (OOP) atau dalam terjemahan bahasa Indonesia-nya lebih dikenal dengan pemrograman berorientasi objek (PBO) (Ahmadian \& Hendri.dkk, 2017). NetBeans merupakan salah satu alat Integrated Development Environment (IDE) yang sejatinya tidak hanya dipergunakan dalam pengembangan perangkat lunak berbasis java, akan tetapi juga di pergunakan oleh beberapa bahasa pemrograman seperti: $\mathrm{C}++$ ataupun PHP (Ahmadian \& Hendri.dkk, 2017).

Sedangkan untuk penyimpanan data menggunakan MySQL yaitu RDBMS yang cepat dan mudah digunakan, sudah banyak digunakan untuk berbagai kebutuhan, serta dikembangkan oleh mysql AB Swedia (Enterprise \& Jubilee, 2015). Dan aplikasi pengembang yang digunakannya adalah ХАMPP. Хатрp adalah paket program web lengkap yang dapat dipakai untuk belajar pemrograman web, khususnya PHP dan MySQL, paket ini dapat di download secara gratis dan legal (Bunafit \& Nugroho, 2013).

\section{HASIL DAN PEMBAHASAN}

Berdasarkan hasil penelitian masalah sebelumnya, peneliti memberikan analisis permasalahan dari sistem pengelolaan data di antaranya

1. belum adanya aplikasi khusus berupa sistem untuk penagihan angsuran siswa pada Bimbingan dan Konsultasi Belajar Nurul Fikri,

2. pencatatan yang bersifat manual sehingga kedang terjadi human error, misalnya kesalahan dalam penulisan data yang menyebabkan data menjadi tidak akurat dan relevan,

3. belum adanya laporan data penagihan angsuran siswa di Bimbingan dan Konsultasi Belajar Nurul Fikri.

Berdasarkan masalah yang terdapat pada BKB Nurul Fikri, penulis memberikan beberapa alternatif penyelesaian masalah tersebut.
1. Membuat sistem aplikasi penagihan angsuran siswa berbasis desktop, agar pekerjaan berjalan lebih efektif dan efisien.

2. Menggunakan database MySQL sebagai media penyimpanan data agar dapat disimpan dengan aman dan meminimalisir kemungkinan kehilangan data.

3. Menggunakan plugin iReport pada Neatbeans untuk membuat laporan yang sudah tersambung dengan aplikasi, agar pembuatan laporan lebih efektif dan efisien. Penggunaaan iReport juga mengurangi kemungkinan kesalahan pada pembuatan laporan.

\section{Diagram Konteks Sistem yang Diusulkan} Berikut adala gambaran sistem yang diusulkan untuk BKB Nurul Fikri:

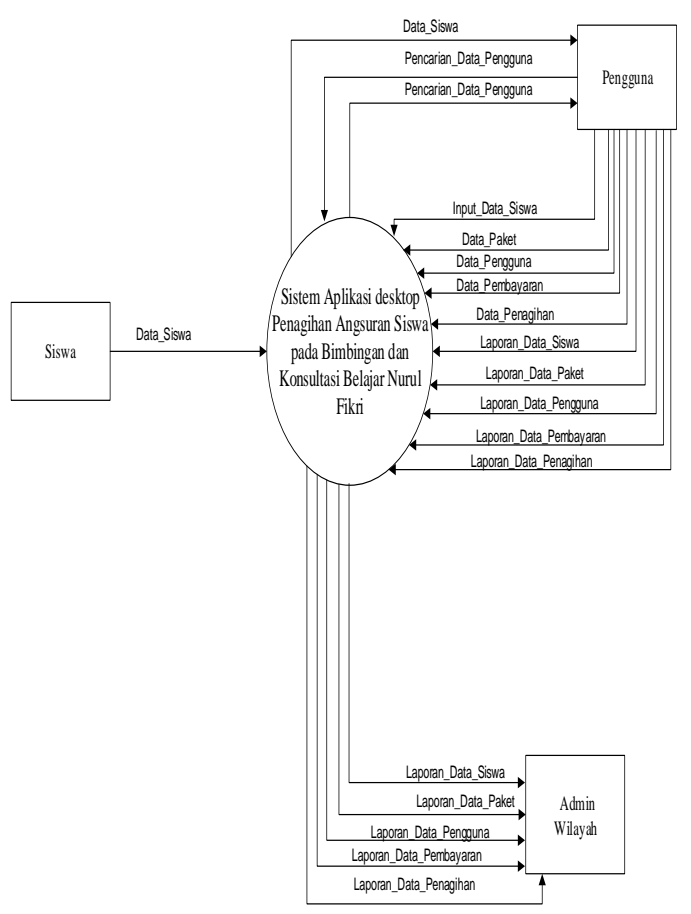

Gambar1. Diagram Konteks Sistem

\section{Diagram Nol Sistem}

Diagram nol merupakan gambaran proses sistem berjalan pada sistem penaghan yang menggambarkan tahap-tahap proses dari diagram konteks, yaitu. 


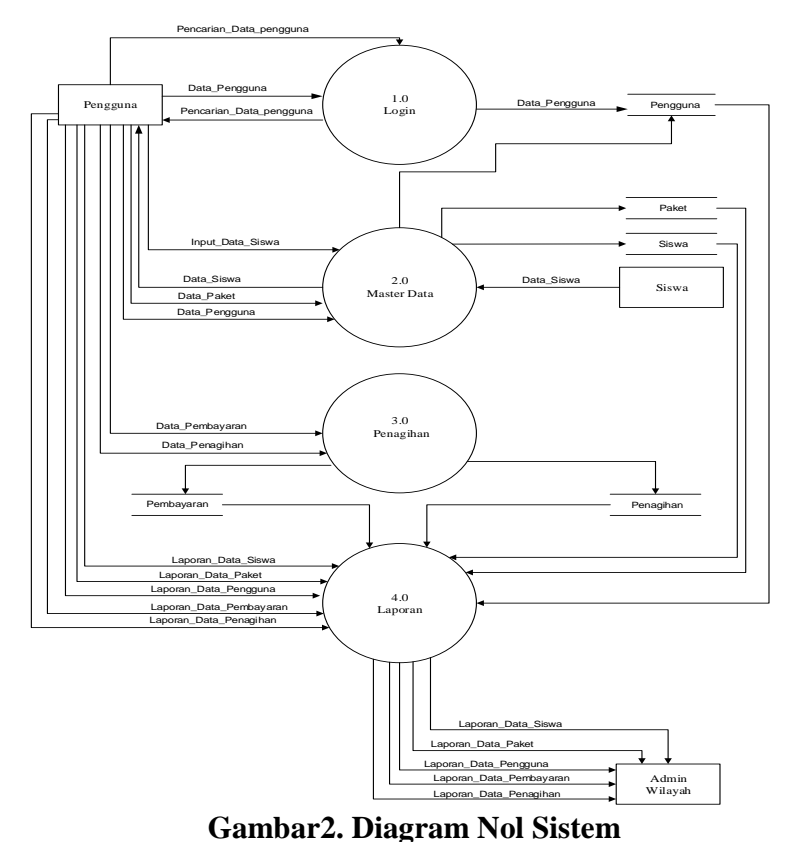

2. Normalisasi Tahap Kedua (2NF)

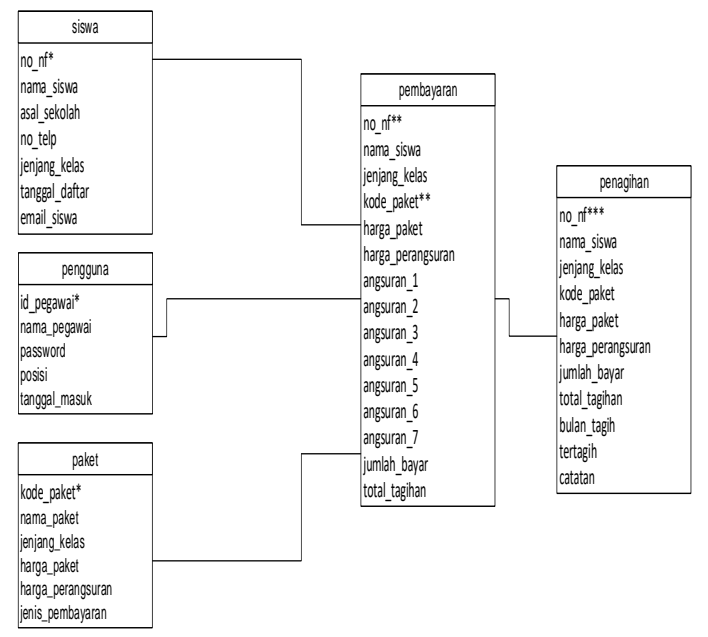

Gambar5. Normalisasi Tahap Kedua (2NF)

\section{Entity Relationship Diagram (ERD)}

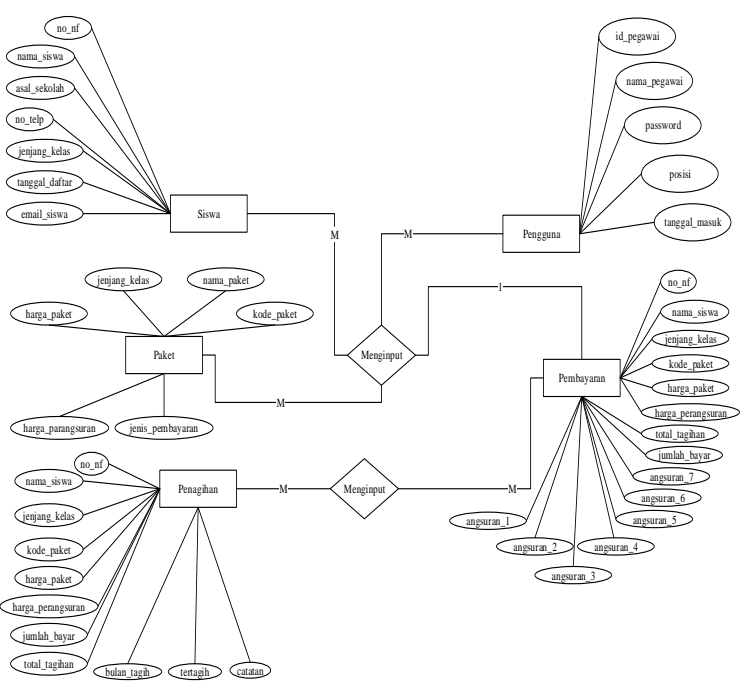

Gambar3. ERD

1. Normalisasi Tahap Pertama (1NF)

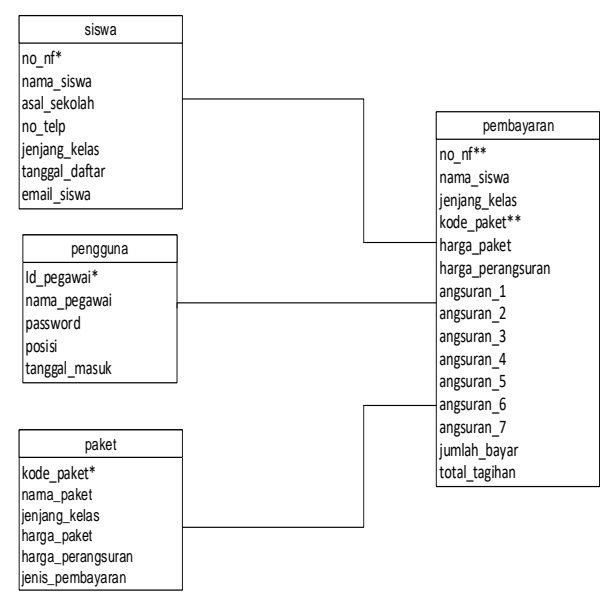

Gambar4. Normalisasi Tahap Pertama (1NF)

\section{Tampilan Menu Login}

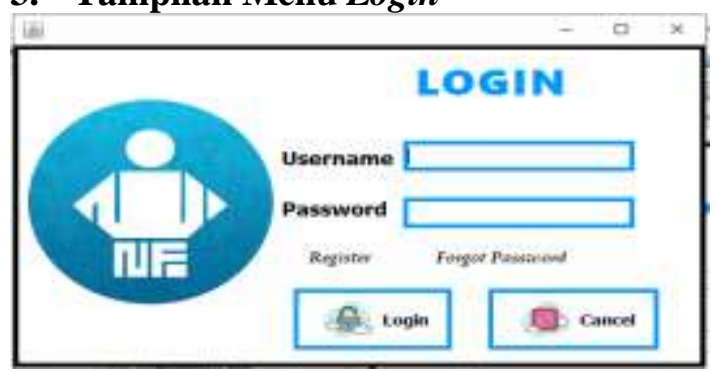

Gambar6. Tampilan Menu Login

Tampilan menu login digunakan sebagai kata kunci sebelum kita memasuki program utama. Login digunakan sebagai kata kunci sebelum kita memasuki program utama. Agar tidak sembarangan orang dapat mengakses program ini. Sehingga dalam form menu kerahasiaannya tetap terjaga dengan baik.

\section{Tampilan Menu Home}

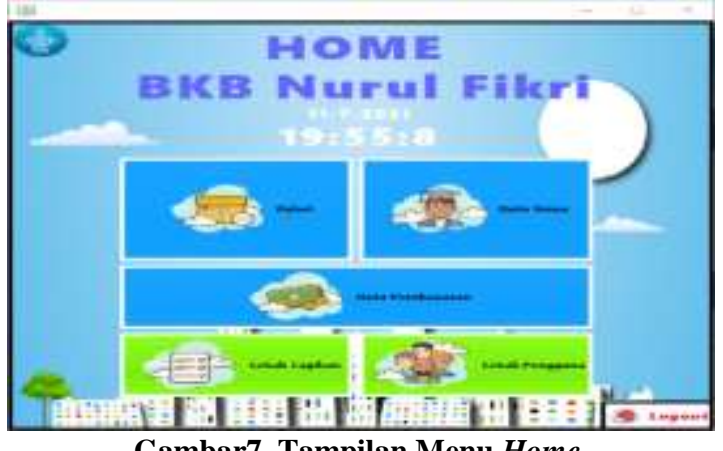

Gambar7. Tampilan Menu Home

Pada tampilan menu utama terdapat menu bar yaitu paket, data siswa, data pembayaran, cetak tagihan dan cetak pengguna. Di dalam menu paket terdapat sub menu yang meliputi data-data yang terdapat dalam biaya paket 
program, di dalam menu data siswa terdapat sub menu yang berisi data-data siswa, di dalam menu data pembayaran terdapat sub menu yang berupa data-data pembayaran siswa, di dalam menu cetak tagihan terdapat sub menu yang berupa data-data yang siap ditagih, di dalam menu cetak pengguna terdapat laporan data pengguna sedangkan pada menu logout terdapat perintah yang membuat kita keluar dari menu utama.

\section{Tampilan Form Data Siswa}

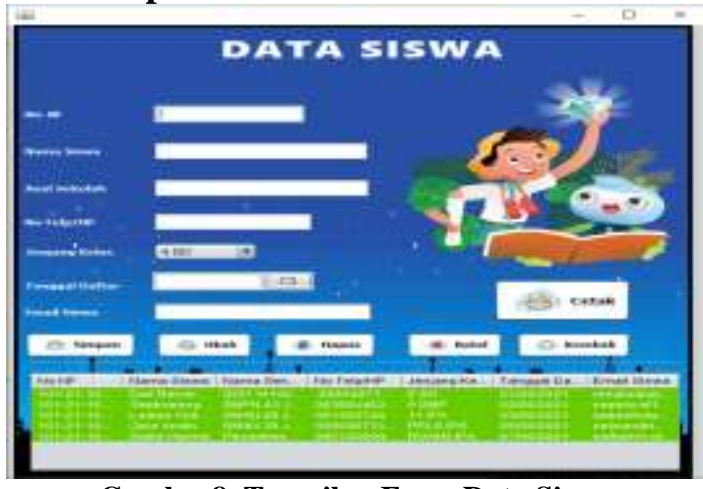

Gambar8. Tampilan Form Data Siswa

Tampilan diatas merupakan tampilan form input data siswa. Form ini memiliki beberapa tombol yang terdiri dari tombol simpan untuk menyimpan data yang telah selesai di-input, tombol ubah digunakan untuk mengubah data yang telah di-input, tombol hapus untuk menghapus data yang telah disimpan, tombol batal digunakan untuk membatalkan data yang telah di-input, tombol cetak digunakan untuk mencetak laporan data siswa sedangkan tombol kembali untuk kembali ke menu utama.

\section{Tampilan Form Data Paket}

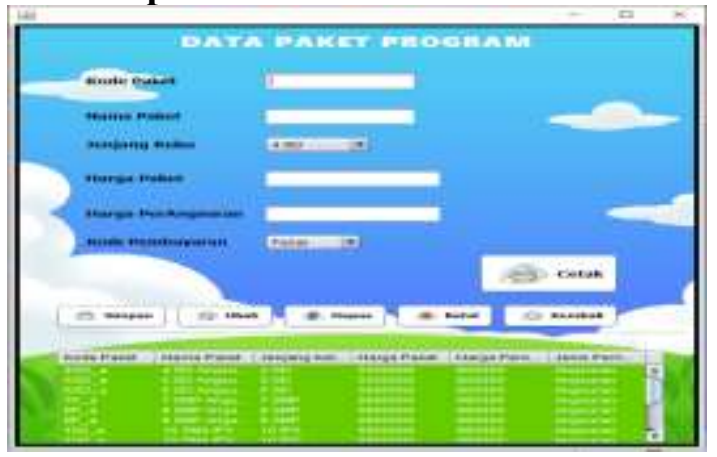

Gambar9. Tampilan Form Data Paket

Tampilan diatas merupakan tampilan form input data paket. Form ini memiliki beberapa tombol yang terdiri dari tombol simpan untuk menyimpan data yang telah selesai di-input, tombol ubah digunakan untuk mengubah data yang telah di-input, tombol hapus untuk menghapus data yang telah disimpan, tombol batal digunakan untuk membatalkan data yang telah di-input, tombol cetak digunakan untuk mencetak laporan data biaya paket sedangkan tombol kembali untuk kembali ke menu utama.

\section{Tampilan Form Data Pengguna}

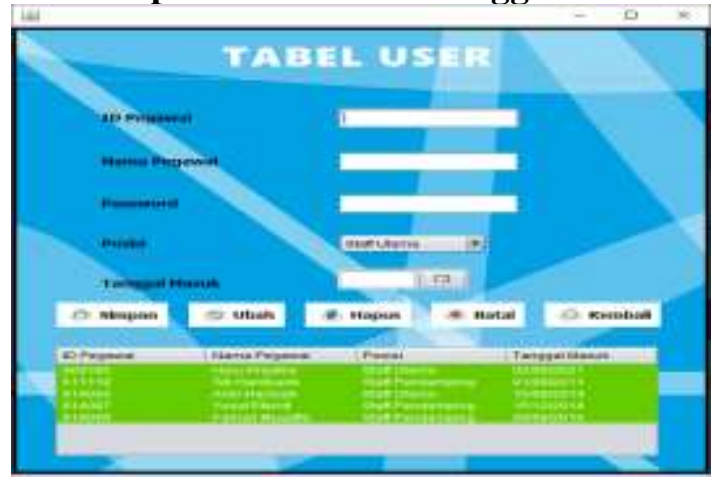

Gambar10. Tampilan Form Data Pengguna

Tampilan diatas merupakan tampilan form input data pengguna. Form ini memiliki beberapa tombol yang terdiri dari tombol simpan untuk menyimpan data yang telah selesai di-input, tombol ubah digunakan untuk mengubah data yang telah di-input, tombol hapus untuk menghapus data yang telah disimpan, tombol batal digunakan untuk membatalkan data yang telah di-input sedangkan tombol tutup untuk kembali ke menu utama.

\section{Tampilan Form Data Pembayaran}

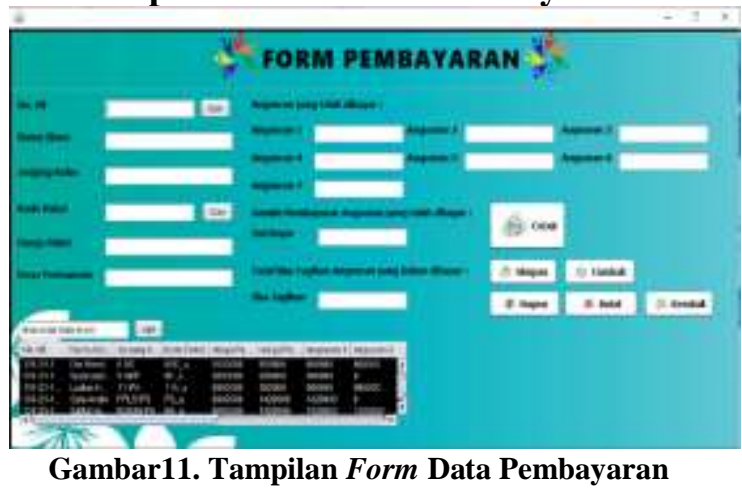

Tampilan diatas merupakan tampilan form input data pembayaran. Form ini memiliki beberapa tombol yang terdiri dari tombol simpan untuk menyimpan data yang telah selesai di-input, tombol ubah digunakan untuk mengubah data yang telah di-input, tombol hapus untuk menghapus data yang telah 
disimpan, tombol batal digunakan untuk membatalkan data yang telah di-input, tombol cetak digunakan untuk mencetak laporan data pembayaran sedangkan tombol tutup untuk kembali ke menu utama.

\section{Tampilan Form Data Penagihan}

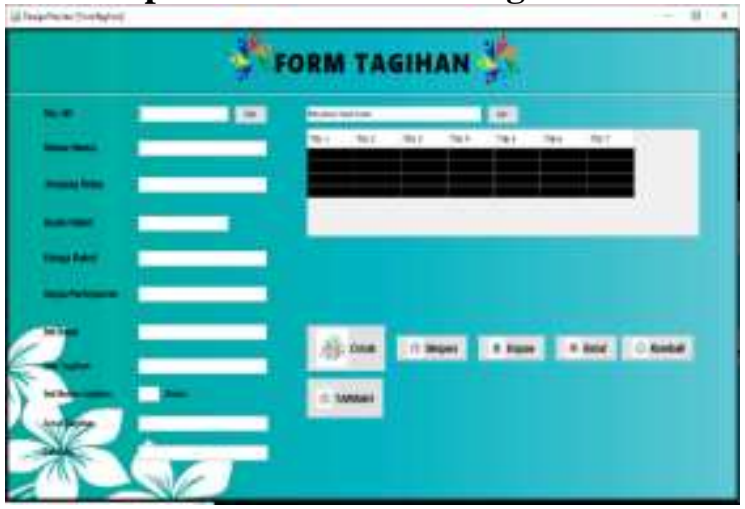

Gambar12. Tampilan Form Data Penagihan

Tampilan diatas merupakan tampilan form input data penagihan. Form ini memiliki beberapa tombol yang terdiri dari tombol simpan untuk menyimpan data yang telah selesai di-input, tombol ubah digunakan untuk mengubah data yang telah di-input, tombol hapus untuk menghapus data yang telah disimpan, tombol batal digunakan untuk membatalkan data yang telah di-input, tombol cetak digunakan untuk mencetak laporan data tagihan sedangkan tombol tutup untuk kembali ke menu utama.

\section{Tampilan Laporan Data Siswa}

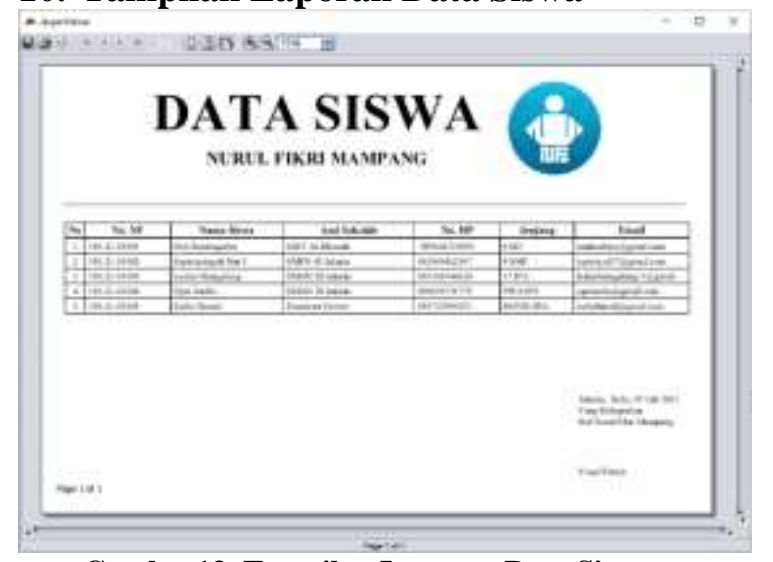

Gambar13. Tampilan Laporan Data Siswa

Pada tampilan layar diatas menampilkan tampilan laporan data siswa yang berfungsi untuk diberikan kepada manajer atau admin wilayah.

\section{Tampilan Laporan Data Paket}

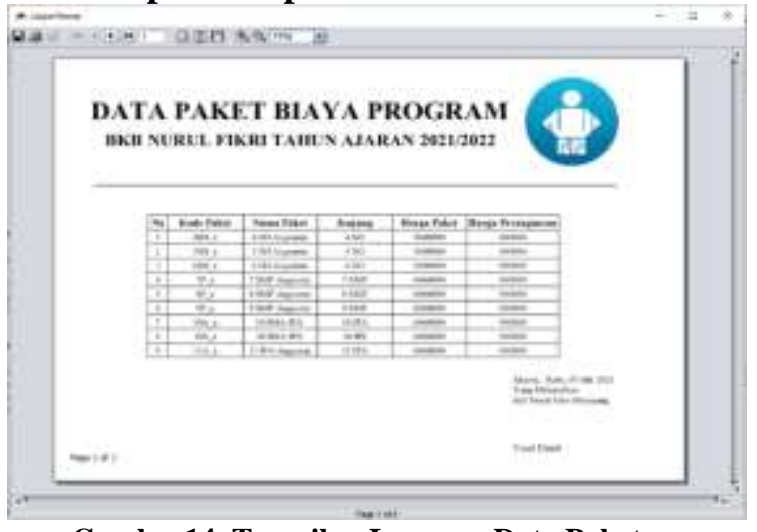

Gambar14. Tampilan Laporan Data Paket

Pada tampilan layar diatas menampilkan tampilan laporan data paket yang berfungsi untuk diberikan kepada manajer atau admin wilayah.

\section{Tampilan Laporan Data Pengguna}

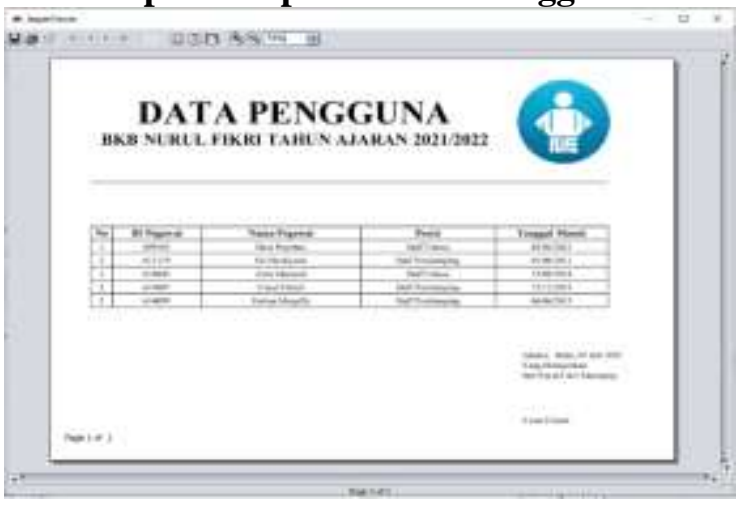

Gambar15. Tampilan Laporan Data Pengguna

Pada tampilan layar diatas menampilkan tampilan laporan data pengguna yang berfungsi untuk diberikan kepada manajer atau admin wilayah.

\section{Tampilan Laporan Data Pembayaran}

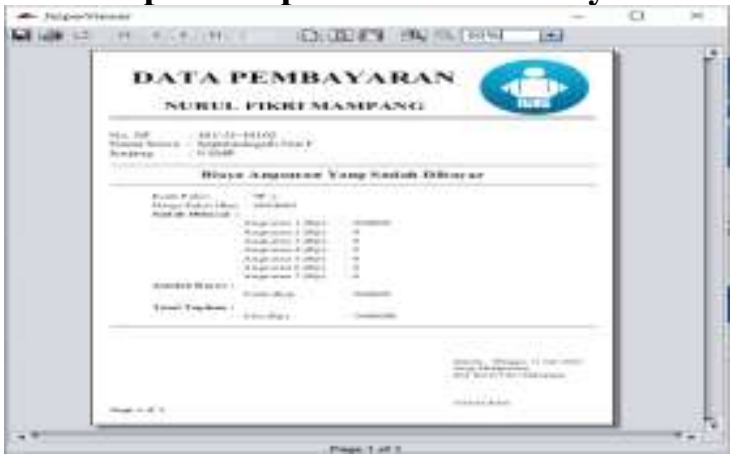

Gambar16. Tampilan Laporan Data Pembayaran

Pada tampilan layar diatas menampilkan tampilan laporan data pembayaran yang dicetak berfungsi untuk diberikan kepada manajer atau admin wilayah. 


\section{Tampilan Laporan Data Penagihan}

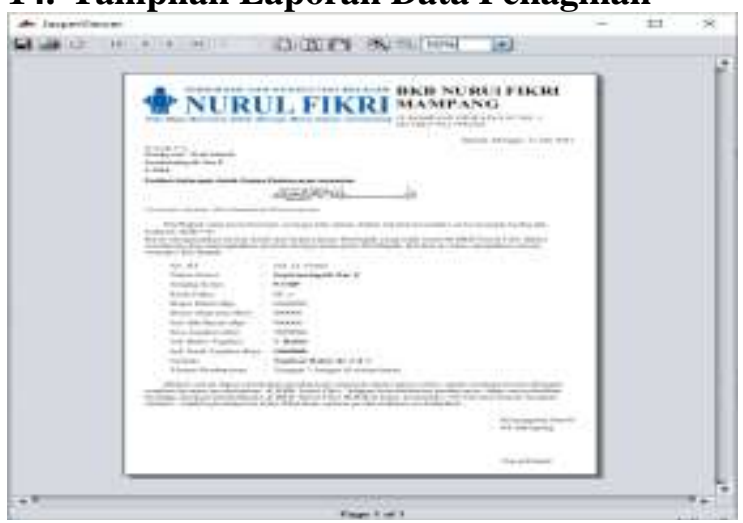

Gambar17. Tampilan Laporan Data Penagihan

Pada tampilan layar diatas menampilkan tampilan laporan data penagihan berfungsi untuk diberikan kepada manajer atau admin wilayah.

\section{SIMPULAN DAN SARAN}

Peneliti memiliki simpulan bahwa dengan menggunakan sistem aplikasi desktop penagihan angsuran siswa yang telah dibuat dengan bahasa pemrograman java dengan editor Netbeans 8.2, permasalahan mengenai penginputan penagihan angsuran siswa, penyimpanan data dengan aman, dan laporan menjadi rapi dalam penyajian dan penyimpanannya menggunakan database MySQL. Selain itu, sistem aplikasi desktop penagihan angsuran siswa yang dibuat dapat meringankan pekerjaan staf admin dalam proses pembuatan laporan berkaitan data penagihan angsuran siswa menjadi lebih efektif dan efisien.

Sejalan dengan sistem yang penulis buat, agar tujuan dan sasaran yang diharapkan bisa tercapai, penulis dapat memberi saran diantaranya adalah sebelum sistem aplikasi desktop penagihan angsuran siswa dijalankan, staf admin harus diberikan penjelasan dengan baik mengenai proses kerja sistem yang akan ditampilkan sehingga tidak terjadi kesalahan. Sistem aplikasi desktop penagihan angsuran siswa pada Bimbingan dan Konsultasi Belajar Nurul Fikri harus didukung dengan sistem yang disiplin dan peraturan yang baik sesuai ketetapan bersama agar berjalan sebagaimana mestinya. Sistem aplikasi desktop penagihan angsuran siswa pada Bimbingan dan Konsultasi Belajar Nurul Fikri dapat dikembangkan kembali dalam hal desain atau penambahan database sesuai kebutuhan pemeliharaan data aplikasi penagihan angsuran siswa.

Hasil penelitian ini selaras dengan hasil penelitian yang menyimpulkan bahwa sistem aplikasi pembayaran siswa memudahkan petugas dalam pembuatan data pembayaran seperti pembuatan laporan dan bukti pembayaran (Rosyida et al., 2018).

\section{UCAPAN TERIMAKASIH}

Terimakasih penulis ucapkan untuk Nurul Fikri Mampang beserta jajarannya yang telah memberikan bantuan dan izin sehingga penelitian ini terlaksana dengan baik.

\section{DAFTAR PUSTAKA}

A.S, R., \& Shalahuddin, M. (2011). Modul Pembelajaran Rekayasa Perangkat Lunak (Terstruktur dan Berorientasi Objek). Modula.

Ahmadian, \& Hendri.dkk. (2017). Mahir Pemograman Visual Dengan Java. Unimal Press.

Bunafit, \& Nugroho. (2013). Dasar Pemograman Web PHP - MySQL dengan Dreamweaver. Gava Media.

Enterprise, \& Jubilee. (2015). Pengenalan Pemrograman Komputer. PT Elex Media Komputindo.

Hidayat, R., \& Cheisviyanny, C. (2013). Pengaruh Kualitas Penetapan Pajak dan Tindakan Penagihan Aktif terhadap Pencairan Tunggakan Pajak. Jurnal WRA, 1(1), 1-20.

Kristanto. (2013). Perancangan Sistem Informasi dan Aplikasinya. Gava Media.

Mamik. (2015). Metodologi Kualitatif. Zifatama Publisher.

Rosyida, M. A., Sufaidah, S., \& Hariono, T. (2018). Sistem Aplikasi Pembayaran Siswa Menggunakan Bahasa Pemrograman Visual Basic 6.0. Saintekbu, 10(2), 61-68. https://doi.org/10.32764/saintekbu.v10i 2.209

Rusman, A., \& Ramanda, K. (2018). Penerapan Global Extreme Programming Pada Sistem Informasi Workshop, Seminar. Informatika, 2(3), 45-52.

Saman, A., \& Arifin, A. (2018). Bimbingan dan Konseling Belajar. CV Budi Utama.

Sutabri, T. (2012). Analisis Sistem Informasi. ANDI. 